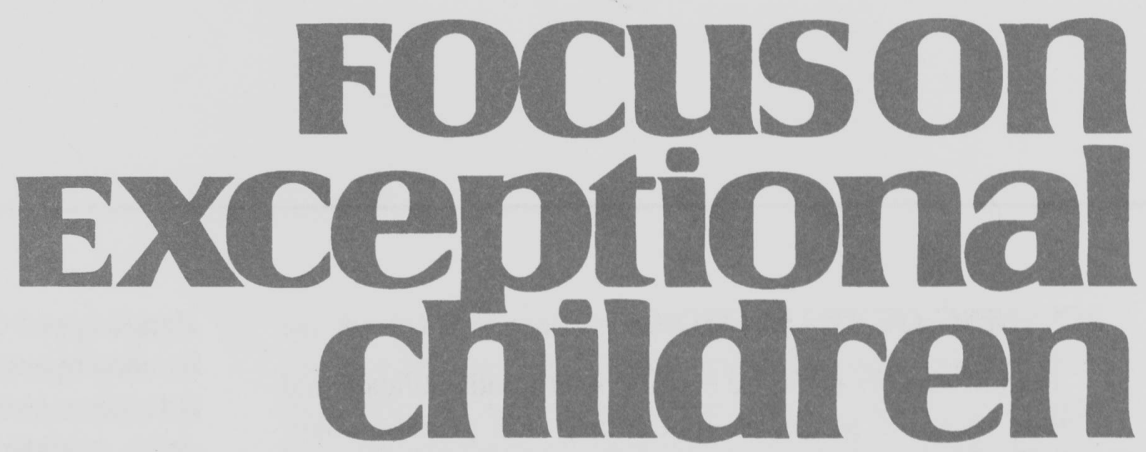

\title{
Strategies for Transition to Postsecondary Educational Settings
}

\author{
Daryl Mellard
}

The goals for this article are consistent with common models of delivering services to students with disabilities in high school and postsecondary educational settings. In the broadest sense the goal is to help teachers and other service providers recognize their roles to ensure that students consider educational opportunities available once they complete their high school requirements and are prepared. More specifically, this article has four objectives:

- To assist teachers in preparing students for the academic and social demands of the postsecondary setting.

- To increase students' awareness of their options in postsecondary educational settings.

- To help teachers evaluate with their students the educational choices available.

- To describe the organization of student services in postsecondary settings.

The article first builds the case for why a larger portion of the LD population should value and utilize postsecondary educational opportunities. The case can be made quite simply that one's quality of life has many dimensions and that the level of educational attainment can contribute positively to those multiple dimensions. These opportunities do not occur by accident but, rather, require planning and preparation. Thus, the planning process and the need to involve many disciplines in repeated monitoring efforts are points of emphasis.

Our findings reveal a postsecondary setting that generally is quite a contrast to the secondary setting. The contrasts are in the available services, the role of the LD specialist, the legal protections, and the demands of the setting on the student.

\footnotetext{
Daryl Mellard is at the University of Kansas. This article was adapted from a chapter in Teaching Adolescents With Learning Disabilities (2nd ed.), edited by Donald D. Deshler, Edwin S. Ellis, and B. Keith Lenz and published by Love Publishing Company.
} 


\section{MEANING OF TRANSITION}

Recent surveys of future employment trends indicate that higher levels of academic functioning and postsecondary training degrees will be needed to compete successfully in the job market. Although students with LD are enrolling more frequently in programs leading to advanced degrees and certification, they often enter these programs poorly prepared emotionally and academically. Many of these young people desperately need a high school curriculum with greater emphasis on their transitional needs (Dowdy, Carter, \& Smith, 1990, p. 346).

The concept of transition is important and comparatively new to special education service providers. Although employment goals have been part of most high school goals in the past, the structure for developing a plan toward that goal was variable prior to 1974 . The requirement for an individualized education program (IEP) for each student receiving special education services provided a uniform structure and required setting long-term goals and short-term objectives as the benchmarks of progress. The IEP requirement was part of the legislation included in the Education for All

\section{Focuson
Exceptional children}

ISSN 0015-511X

FOCUS ON EXCEPTIONAL CHILDREN (USPS 203-360) is published monthly except June, July, and August as a service to teachers, special educators, curriculum specialists, adminiștrators, and those concerned with the special education of exceptional children. This publication is annotated and indexed by the ERIC Clearinghouse on Handicapped and Gifted Children for publication in the monthly Current Index to Journals in Education (CIJE) and the quarterly index, Exceptional Children Education Resources (ECER). The full text of Focus on Exceptional Children is also available in the electronic versions of the Education Index. It is also available in microfilm from Xerox University Microfilms, Ann Arbor, MI. Subscription rates: individual, \$36 per year; institutions, $\$ 48$ per year. Copyright (C) 2005, Love Publishing Company. All rights reserved. Reproduction in whole or part without written permission is prohibited. Printed in the United States of America. Periodical postage is paid at Denver, Colorado. POSTMASTER: Send address changes to:

Love Publishing Company

Executive and Editorial Office P.O. Box 22353

Denver, Colorado 80222

Telephone (303) 221-7333
Handicapped Children Act (EHA), Public Law 94-142, and its accompanying regulations. Through development of the IEP, the multidisciplinary team, including parents and students, could customize and plan curricular activities for individual students. This structure broadened the educational opportunities for students with disabilities.

In 1985 Will (1985) added a special emphasis for high school programs for students with disabilities, focusing on these students' transition to successful employment. Her definition of transition was "an outcome-oriented process encompassing a broad array of services and experiences leading to employment" (p. 1). The singular emphasis on employment as an outcome spurred further efforts to increase the quality of special education programs for a more broadly defined outcome.

Several other writers (e.g., Halpern, 1985; Wehman, Kregel, \& Barcus, 1985) challenged the federal perspective as articulated by Will (1985). Halpern argued that the appropriate outcome target should be community adjustment and that employment is only one index of the level of that adjustment. Community integration may have been a new concern or target for student outcomes for many school districts (NICHCY, 1993, p. 13).

In federal legislation the term transition services means a coordinated set of activities for a student, designed within an outcome-oriented process that promotes movementusfom school to postschool activities, including postsecondary education, vocational training, integrated employment (including supported employment), continuing and adult education, adult services, independent living, and community participation (Federal Register, September 29, 1992). For the purposes of this article, the transition to postsecondary educational settings refers to the sequential process of students' completing secondary school requirements and planning and participating successfully in further formal educational activities in a degree or certification program. Postsecondary programs include community colleges, vocational and technical schools, and 4-year colleges and universities. Successful participation in these programs requires active long-range planning by students, their parents or guardians, and school staff. It is essential that students have a thorough understanding of the consequences and options for their postsecondary plans.

Completing the secondary school requirements does not always mean graduating with a high school diploma. For some students the best alternative is to pass high school equivalency examinations or the five areas of the General Educational Development (GED) exam. In working with the students, these alternatives to high school graduation should be considered carefully in light of the students' interests, motivation, and availability of program support. We need to realize that these alternatives to a traditional high school
Stanley F. Love Publisher 
diploma may be the ticket for the student to access a postsecondary setting more quickly. Teachers do not want to advocate dropping out of school, but if students are headed out the door already, they should have an alternative. They need to know that there is no yellow brick road to an easy lifestyle but that the road can take them to a postsecondary setting in which they can pursue their educational goals.

\section{Participants in Transition Planning}

The planning process should involve the student's teachers and parents, the high school counselor, the vocational rehabilitation counselor, an admissions counselor to a postsecondary educational setting, and the student. Wehman et al. (1985) suggested adding to the team an adult service system representative and possibly an employer. The employer would be chosen to represent the perspectives of other employers and to describe the most important general characteristics that employers evaluate in hiring, retaining, and advancing their employees. Even if a student's initial interest may be to pursue additional education, the employer can be a resource to serve the student's eventual goal of employment that will support an independent lifestyle.

Transition planning is a student-centered activity that requires collaborative effort and demands that the participants share responsibilities (National Joint Committee on Learning Disabilities, 1994). Key team members include special education staff, parents or guardians, high school counselors, employment representatives, vocational rehabilitation counselors, postsecondary setting admissions counselors, and the student. This list is a broader representation of perspectives than that described by Wehman et al. (1985) or later by Rojewski (1989). Second, this listing was organized with an emphasis on students' continuing their formal education. Clark and Kolstoe (1990) included many of these same individuals in their discussion on planning students' transition to settings different from postsecondary educational settings. The various staff members are included to emphasize the importance of this transition planning. Although representatives of the school staff likely are part of the IEP team, other disciplines and settings have to be represented to add a broader perspective to the discussions. For example, vocational rehabilitation requires representation because this agency is infrequently associated with LD services (Osgood-Smith, 1992) but should have an expanded role in light of the agency's change in LD definition and policy.

We generally believe that students should contribute to the planning process. Students are not always willing participants, but including them at least as observers is important. Until recently few models have been offered for including students as active participants (Van Reusen \& Bos, 1994). As the transition plan takes shape, though, they likely will see the value of reacting and offering their own suggestions for an effective plan. Their participation will heighten their motivation to achieve the agreed-upon goals. Also through their self-assessment, they can identify their strengths and weaknesses and set their priorities. They can describe the accommodations that work best for them to minimize their disability.

Kravets (1993b) developed several worksheets and selfassessments that are helpful in evaluating postsecondary educational options. Several features make her material particularly helpful. First, it includes sections relevant to the student's self-assessment as well as principles for evaluating colleges and the LD services available. In another section she outlines a four-step planning section of the tasks a student should complete in planning postsecondary options.

Davie (1987) provided an assessment that a teacher or a counselor might complete with a student to evaluate the student's level of independence and preparation for a postsecondary setting. Some of the questions in that assessment are:

- How do you best learn something new? Is it easier when someone shows you how to do a task? Or do you prefer a slow, careful explanation?

- What kinds of places do you enjoy working in, and what are you good at doing that could lead to a meaningful job?

- Do you have good work habits?

- Are you on time with completing tasks and assignments?

- How well do you work with others of the same age? With others who are older?

- How are you going to handle the criticism that comes with high expectations from others such as a college instructor or employer?

- How do you manage your resources (e.g., energy, health, time, and money)?

- How many of the activities required for living independently do you manage on your own now? Those activities might include meal planning and preparation, doing laundry, paying bills, keeping a budget, and keeping materials organized.

The questions Davie (1987) developed are not intended as exhaustive but should provide a catalyst for discussions. They are best reviewed with the student or as a small-group activity with several students. Students need to be selfadvocates - which at 16 to 18 years of age may be difficult but certainly should be encouraged. The educational environment and ITP- and IEP-related meetings provide some of the best training opportunities for students to develop their self-advocacy skills and gain a broader understanding of career and lifestyle issues they are confronting. 


\section{Value of Postsecondary Education}

To most students with learning disabilities and, perhaps, their parents and guardians, the prospect of students continuing their education beyond the secondary level may seem foolhardy. After all, from their perspective, the most readily apparent manifestation of their learning disability is through classwork requirements. This disability was identified as such in a school setting, not in the church choir, the doctor's office, or a department store. The value attached to higher education, however, is no different for any student with or without disabilities.

Regardless of a person's attributes, quality of life is measured by the same scale. Therefore, an important consideration for students with disabilities is to realize that they face a greater imperative for developing their skills. That imperative exists because, regardless of the level of their success, they always will have to confront and consider the severity of their disability. Although the disability may exclude them from a few activities or career choices, it will influence their performance in any endeavor. This reality should be presented to the students and parents as part of their orientation to being a young adult or adolescent with disabilities. The student and his or her parents may have come to realize the effects in an educational setting, and that setting has had the most supportive environment. In comparison to the work environment, even the postsecondary setting is more accommodating.

In a number of studies young adults were asked about the quality of their lives since leaving high school. Quality of life was considered from several dimensions including their living situation, employment opportunities, and educational goals. Halpern (1993) suggested that three basic domains of outcomes are almost always worthy of assessment. To understand a person's quality of life, one must examine the success achieved in three domains:

1. Physical and material well-being (including physical and mental health, food, clothing and lodging, financial security, and safety from harm)

2. Performance in a variety of adult roles

3. A sense of personal fulfillment (including happiness, satisfaction, and a sense of general well-being).

Halpern's second category of adult roles is much more encompassing and should be examined closely across several outcomes. Regarding various adult roles, Halpern identified eight areas of outcomes:

1. Mobility and community access (e.g., effectively using some form of transportation)

2. Vocation, career, and employment (e.g., having a job that reflects a career interest)
3. Leisure and recreation

4. Personal relationships and social networks (e.g., maintaining a network of friends)

5. Educational attainment (e.g., earning a high school diploma)

6. Spiritual fulfillment (e.g., participating in spiritual activities of choice)

7. Citizenship (e.g., voting)

8. Social responsibility (e.g., not breaking laws).

Why should these domains and areas of outcome be of concern to teachers, and, more important, to students? A person's quality of life can be examined in these domains. This model for quality of life provides teachers a framework for identifying a student's needs and planning appropriate postsecondary learning experiences. To help students consider their options for further education, teachers might want to provide students and their parents information about the research findings of the adult population with $\mathrm{LD}$ and of follow-up and follow-along studies. Halpern's framework was used to help organize the findings from these studies. This organization also would be useful in developing students' IEPs and ITPs, and the framework could be useful for students' self-assessment and goal setting. Two areas have been singled out here because they appeal to adolescents in particular: employment opportunities and financial earnings.

Adolescents seem especially prone to dismiss the value of education and have an overly optimistic view of their potential to live and work independently without education. The following list of authors and the publication dates of research articles came to a similar conclusion about employment outcomes for students with LD. These studies examined the employment pattern of students who were in high school and students who had graduated or left high school. The students who were no longer in school were followed for as long as 3 years after leaving school. Although some exceptions were reported, all of these 13 studies reported that the vast majority of students were employed in entrylevel, base-wage positions and had low rates of advancement or improved positions. Examples of these kinds of jobs include laborers, sales clerks, food service workers, and the armed forces. The researchers include the following:

Cobb and Crump (1984)

Edgar (1987)

Fourqurean and LaCourt (1990)

Fourqurean, Meisgeier, Swank, and Williams (1991)

Haring, Lovett, and Smith (1990)

Malcolm, Polatajko, and Simons (1990)

Neubert, Tilson, and Ianacone (1989)

Scuccimarra and Speece (1990)

Shapiro and Lentz (1991) 
Siegel and Gaylord-Ross (1991)

Siegel, Robert, Waxman, and Gaylord-Ross (1992)

Sitlington and Frank (1993)

Sitlington and Frank (1990)

The issue is not the value of any job over another. Employment is important for a number of reasons. Nevertheless, the positions obtained by individuals with LD most often offer little opportunity for advancement. Great competition from others in the workforce exists for these jobs, and continued education would open additional opportunities to other occupations, not limit them.

Other researchers have reported more positive outcomes for individuals with LD (Bruck, 1985, 1987; Adelman \& Vogel, 1990), but these outcomes were for individuals who had attended more selective schools and received extensive interventions early in their education. The differences suggest that factors such as parental influence, educational attainment, and quality and length of interventions can make a difference, but these factors do not exist for the majority of students with LD. As the teacher and the other IEP team members work with these students and parents, the employment outcomes reported from follow-up and follow-along studies can be important in developing a sense of urgency to plan additional educational opportunities.

Another outcome for a student to consider is that jobs vary in potential earnings. As a simplistic example, a student who mows lawns in a northern state can expect to earn an income during a short growing season and, for at least that reason, a year-round job at minimum wage would provide greater earnings potential. A few lessons on the cost of living and lifestyle goals should have a sobering effect on the limits of a secondary education. For most students postsecondary education can be translated into better jobs and a higher quality of life.

Given the kinds of occupations described here, one might expect that earnings would be low. Studies examining the earnings of students with LD who left school early or had little postsecondary training or education have found consistently that more than half of the students were earning less than $\$ 5$ an hour. A relatively easy lesson for students to do is a quick calculation of living expenses. One can see that $\$ 5$ an hour provides a base wage but little beyond the minimums, and in some locations it would not meet the minimum requirements for affordable housing. In addition, a quick lesson about employee benefits likely would lead the student to conclude that entry-level jobs offer few benefits such as health or dental insurance, sick leave, vacation leave, maternity leave, or profit sharing. In six studies (Fourqurean et al., 1991; Neubert et al., 1989; Scuccimarra \& Speece, 1990; Shapiro \& Lentz, 1991; Siegel \& GaylordRoss, 1991; Sitlington \& Frank, 1990), few of the students received the described employee benefits. The vast majority of students had jobs without significant benefits.

Students should be able to figure out that jobs that pay near the minimum wage and offer few, if any, benefits do not represent the best opportunities. These earnings would place the student near the government's hypothetical poverty line. If those findings are not dismal enough, the real kicker is that almost three fourths of these students wind up living at home (Fourqurean \& LaCourt, 1990). That should be frightening to the students and their parents alike. The parents are not likely to miss the significance of the discouraging statistics and, as a consequence, are likely to become quite involved in planning a successful transition. At this point astute teachers can extend the carrot of postsecondary educational opportunities. Teachers also should be aware of some of the factors that inhibit students' successful participation in postsecondary educational settings.

\section{DIFFERENCES BETWEEN HIGH SCHOOL AND POSTSECONDARY SETTINGS}

Ask a parent to name the biggest difference between high school and postsecondary settings, and the response might be that the college charges higher tuition! Although this may be true when comparing most 4-year colleges and universities with high schools, that financial difference is not so disparate in community college settings. The most significant differences, however, are more programmatic. The important differences concern the curriculum, instructional methods, and supportive services model.

The postsecondary setting offers the most significant opportunity for students to acquire the knowledge and skills for vocational attainment, which is tied to more positive outcomes, especially for students in vocational educational settings. High school can be seen as preparatory for the more specific postsecondary training.

The differences between high school and college are amplified by other changes that occur concurrently. For example, postsecondary settings for many students require leaving home. This can present significant challenges for students who have difficulty with the required social competencies (Mellard \& Hazel, 1992; Putnam, 1984; Osgood-Smith, 1992). Brinckerhoff, Shaw, and McGuire (1992) and Dalke and Schmitt (1987) identified related areas of change including the decrease in contact among teachers and students, the increase in academic competition, the change in the students' support network because they are more independent, and a greater expectation that the students will achieve on their own.

NICHCY (1991) highlighted some of the significant differences between high school and postsecondary settings in terms of the available special education services. Among those differences is that the high school most likely is the 
last setting in which comprehensive services are available. These services included educational programming and other supports such as the entitlement to individualized education and psychological assessments, and a multidisciplinary team for planning and providing special educational and related services (e.g., speech and language therapy, occupational and physical therapies, and adaptive physical education). Leaving high school creates a void that usually has been filled by the parents and family, as well as a carefully developed ITP and a high school program that provides follow-up to its graduates.

Teachers will want to point out to students and their parents that special education is different in postsecondary settings. It is replaced by some other organization such as student services, student assistance center, or disabled students' services. These differences are more than a name change. They reflect significant philosophical, legal, and practical changes.

In grades $\mathrm{K}-12$ special education services are delivered through a federally legislated system that provides financial support to the states. In addition to the federal financial support, each state provides support for the added costs of services and for certifying instructional and support staff for students with disabilities. This federal support is not provided to any postsecondary setting. Similarly, in only a couple of settings is state support offered for higher education costs for students with disabilities. Philosophical differences influence these financial and support services offered to students after they leave high school. The high school special education staff might discuss how their services should be structured to ensure a smoother transition to postsecondary settings and follow-up of their school leavers. As part of planning the ITP, the students might be asked to identify the services they currently receive. For comparison, they could contact nearby postsecondary institutions and identify available services. This exercise will illuminate a different perspective on secondary and postsecondary services.

\section{Barriers in a Postsecondary Setting}

The differences between high school and college can be challenging to many students. In addition, a number of factors have been identified that decrease the likelihood of a student's success in postsecondary settings. Prater and Minner (1986), Rosenthal (1986), and Putnam (1984) reviewed related literature regarding barriers. Among the barriers are three that are cited frequently: (a) the student's inappropriate, or lack of, preparation, (b) negative attitudes among faculty, and (c) lack of comprehensive support programs.

\section{Postsecondary Preparation}

A student's preparation for college includes academic preparation and the ITP. Some of the common interventions in high schools may support a student in that setting but provide little support outside that setting (Mangrum \& Strichart, 1988; Mellard \& Clark, 1992). Examples of the "getting-by curriculum" include interventions that rely heavily on tutoring in the content areas, basic skills, workstudy, and functional curriculum (Mellard \& Clark, 1992). Students can complete their high school requirements through these intervention and curricular models, but have few of the skills required in higher education settings. Thus, students, teachers, and parents need to recognize the fundamental importance of the curricular and instructional decisions at the secondary level. The curricular decisions involve which coursework the student will complete.

The instructional decisions involve the methods used in providing the instruction. Instruction delivered through tutorial models may provide successful completion, but is that model the best for preparing the student for the level of independence expected at the collegiate level? Does the curriculum recognize the differences between high school and postsecondary settings and have options for students transitioning to the postsecondary setting?

In spite of the learning disability, students with LD need content instruction that will match their postsecondary plans. This need is no different than that for other students except that other students have access to the mainstream high school programs. Some of these course offerings may be unavailable or at a different level of academic rigor for the LD student. Students can wind up in basic skills courses that are not supportive of a postsecondary placement (Bursuck, Rose, Cowen, \& Yahaya, 1989).

The best approach to this programmatic issue is through the content that gets included on the student's IEP and ITP. By identifying early in high school the range of postsecondary options the student would like to consider, the ITP and IEP can be developed accordingly. In the simplest plan the students would (a) identify the postsecondary settings they would like to consider, (b) review the entrance requirements to those settings, (c) review the kinds of secondary courses needed to meet those requirements and the high school's course requirements, and (d) match those requirements to the offerings at the secondary setting. The earlier this task is initiated, the greater flexibility the student will have in planning the high school curriculum. Any forwardthinking high school student interested in postsecondary education would follow the same strategy. The ITP team should serve as the catalyst that encourages the students' deliberations and supports their initiative.

When the instructional methods are considered, the ITP and IEP team again must consider students' postsecondary plans. These teams do not want to provide instruction that only ensures high school completion. They, too, need to have an informed vision of the setting demands a student 
will encounter in postsecondary settings and the available services. Experience is a valuable teacher. Guided experience with feedback is the needed teacher for these students with LD.

\section{Faculty Attitudes}

Some observers have commented on the change of attitudes in instructional staff between primary grade level and elementary level to middle school, and on up through high school and postsecondary settings. The change is that a higher expectation is placed on the student to acquire the content and that the instructor is seen as presenter of that knowledge. The progression also corresponds to a decrease in teaching the tool skills for learning such as reading, arithmetic, and writing, and an increase in the student's independent application of those skills in learning the needed course content. At the college or university level in particular, scholarship and research interests dominate, and the setting is not viewed as a social service agency designed to accommodate all interested applicants. In some college settings these values are demonstrated in the admissions standards and student support services offered (Putnam, 1984; Rosenthal, 1986). For example, the more selective the admissions standards, the more specific and narrow is the college's perspective on the students it enrolls and graduates.

These different perspectives across the grade levels reveal a greater emphasis on maintaining the integrity of the academic program and on students' meeting degree requirements. The shift is not unwarranted on some accounts, but it also places greater burdens on the students. Students must work to meet the requirements of the degree, and those requirements are described clearly in terms of number and distribution of course credits. This standard for excellence means that all students should be treated equally. The requirements and treatments must be the same for all students. Equal treatment can be a handicap for students with disabilities. Their disabilities mean that they are not able to work on an equal footing with their nondisabled peers.

The alternative to equal treatment that at the same time can maintain the instructor's and institution's desired level of excellence is to provide equitable treatment (Lundeberg \& Svien, 1988; Oliker, 1989). Equitable treatment emphasizes maintaining a high standard but providing accommodations that permit the student to meet course, department, and college requirements (Nelson, Dodd, \& Smith, 1990; Vogel \& Sattler, 1981).

\section{Support Programs}

Earlier the high school and postsecondary settings were differentiated on a number of dimensions. One of the most critical dimensions for the student with LD is the variation in support programs offered in the postsecondary setting.
Provision of services is based on the individual institution. Rather than describing a continuum of services as required in the $\mathrm{K}-12$ system, the postsecondary setting chooses its own model for services. This lack of uniformity could be a barrier to students because the opportunity for attending different postsecondary settings is limited by costs, distance from home, admissions requirements, career interests, campus size, and support groups. These issues are minimal in a high school setting. Yet, in planning a successful transition to a postsecondary setting, these issues must be considered carefully.

Variation in support programs and services has been well documented in a number of books and materials. These materials were designed to acquaint interested audiences with this range in services and to assist in choosing among the alternatives. The high-tech solution also is available. MatchMaker (Alexander \& Rolfe, 1992) computer software is for individuals who want a high-tech alternative to printed media and want to compare a student's interests with the services available in postsecondary settings. Depending on the amount of use the software might get and the availability of hardware, MatchMaker may be a good alternative to printed media. This software has yearly updates.

\section{Additional Barriers}

In addition to the previous barriers discussed, several others contribute to making postsecondary transition difficult for students and the educational staff who want to assist with transition plans. One of these factors is the variation in the standards found in postsecondary settings for identifying and serving students with LD. No single characteristic is sufficient for identifying students with LD (Mellard \& Deshler, 1984). At the extreme is a great variation in the kinds of information on which LD identification or eligibility for services is based. Unlike elementary through secondary schools, most postsecondary systems or even individual settings lack a uniform set of standards for making the determination of LD and appropriateness for services. Because no federal legislation such as PL 101-467, the Individuals with Disabilities Education Act of 1990, covers postsecondary settings and few state regulations have been developed, even greater variation is encountered than what is observed in school districts (Brinckerhoff et al., 1992; Mellard, 1990). The important consequence is to realize that the individual program determines the services and requirements for accessing those services.

California's state university and community college systems are two exceptions to this trend with systemwide eligibility models (Chancellor's Office, 1988). In California community colleges the programs that provide services to students with LD are entitled to reimbursement from the state for the direct excess cost of providing those services. 
To ensure consistency across the 105 community colleges, the colleges have developed their own eligibility model (Mellard, 1990). Thus, the colleges have a financial incentive for having students meet their eligibility model. A benefit of this system is that it is recognized within the state's university system. Students who are judged eligible for services in the community colleges are eligible when they transfer to a 4-year program to continue their work toward a degree. This reciprocity is valuable to ensure a smooth transition between institutions.

As an enrichment activity, the teacher might contact five or so recent graduates from the program or include some students who exited early and arrange for them to visit the high school students. Have the students spend some time planning the questions they would like to ask the alumni. The questioning could be a one-on-one interview or a panel discussion with a moderator. The questions should address some changes the alumni have experienced since leaving high school. Alumni who have had a range of postsecondary experiences should be included to broaden the students' perspectives. Teachers also might want to include the students' parents. The discussion should be short and focused.

\section{STUDENT CHARACTERISTICS}

\section{Who Transitions}

Not many students with LD attend a postsecondary school to continue their education (Fairweather \& Shaver, 1991; Valdes, Williamson, \& Wagner, 1990). The ratio is approximately three to one nondisabled to students with LD who attend a postsecondary school within a year after leaving high school. Our experience suggests that unless students with LD enter a postsecondary setting within the first year of leaving the secondary setting, the likelihood that they will participate later drops significantly.

Recent studies document that an increasing proportion of students with LD are attending postsecondary classes. The importance of this change is that colleges, community colleges, vocational and technical schools will become more sensitive to the needs of a more diverse population. As a consequence, the student should find services easier to access and more abundant. Also, programs likely will have more specific guidelines regarding eligibility for services.

The students with LD will demonstrate to colleges that LD cannot be characterized by a specific achievement disability and that accommodations must be tailored individually. From one perspective, no rules exist for the college to follow in learning to deal with the students with LD. Each student must be considered individually. This lesson likely was learned earlier in the $\mathrm{K}-12$ system, as most of these students are products of that system.
Students with LD will not likely be alone as they attend a postsecondary setting. Several estimates suggest that LD represents one of the largest groups of students with disabilities on campus (CLD, 1993; Fairweather \& Shaver, 1991). Fairweather and Shaver found that $17 \%$ of students with LD enrolled in some type of course in a postsecondary setting- $8.5 \%$ in a vocational course, $6.8 \%$ in a 2 -year course, and $1.8 \%$ in a 4-year course. The Council for Learning Disabilities (1993) reported that 9\% of all students with LD were enrolled in 2-year or 4-year colleges. Elksnin and Elksnin (1996) reported that few students attend a 4-year college or university. They reported that fewer than $2 \%$ attended 4-year institutions, a value closer to Fairweather and Shaver's findings.

The staff and parents working with the student to prepare for postsecondary settings also should consider an important statistic regarding when these students participate. Results from several studies confirm that students who left school and participated in postsecondary educational opportunities did so within a year after leaving the secondary setting (Eagle, Fitzgerald, Gifford, Zuma, \& MPR Associates, 1988; Jones, Sebring, Crawford, Spencer, \& Butz, 1986a, 1986b). Therefore, the inclination to wait out a time before enrolling in a postsecondary program will decrease substantially the probability of reentering. Participation might be likened to a game of poker. Once a person is out of the betting, he or she is out for the rest of the hand. In this case, folding your hand likely will mean that the student will continue to hold those same losing cards. The best opportunity for participation comes with the support of parents and the high school team.

\section{Who Succeeds}

An important consideration is knowing which students are likely to be successful in the various postsecondary settings. Postsecondary educational opportunities are quite varied. Students have choices for colleges, universities, 2-year colleges, vocational and technical schools, and adult education. These choices must be considered carefully given the low completion rates. Approximately $30 \%$ of students with LD complete degrees successfully at community colleges and 4-year colleges and universities (Bursuck et al., 1989).

As the IEP and ITP are being developed in high school, realistic goal setting should take precedence. When considering alternative outcome goals, attention should be directed to narrowing the postsecondary settings to those that are most realistic for the student's skills and career interests. First, the high school's and state's graduation requirements must be considered. This first hurdle can be formidable, particularly as recent reforms in some states have increased the number of hours or credits required for graduation and implemented a minimum competency or 
exit testing program (Mellard \& Clark, 1992). In light of these requirements, a student may elect to spend an extra year in high school to be better prepared and able to devote attention to more challenging content (CLD, 1993).

Miller, Snider, and Rzonca (1990) analyzed data from Iowa's follow-along and follow-up studies to learn which factors contributed to students' participation in postsecondary education. The assessed differences were in the areas of intellectual ability, reading, and math achievement, involvement in extracurricular activities, and access of community resources. In cognitive ability and achievement the differences were not too surprising. The brighter and more highly skilled students were more likely to participate. The assessed ability and achievement levels of students in postsecondary education, however, were below average. The intellectual ability level was a standard score of 96 , and the grade-level equivalencies in reading and math were in the 7 th-grade range. These low scores might encourage a large number of students to pursue a postsecondary education, albeit at one of the less selective choices of a community college or a vocational or technical school. That's encouraging because few students with LD are likely to achieve at a 12th-grade level and might needlessly rule out postsecondary educational options.

Our work with the California community college system provided an opportunity to describe numerous characteristics of students with LD in this postsecondary system. Approximately $1.2 \%$ of the students in the California community colleges are served as LD. A study completed in 1992 (Mellard, 1993) provided extensive details about the ability and achievement levels of students in the system. Students from 21 of California's 105 community colleges were tested. The test scores included the Full Scale IQ score from the Wechsler Adult Intelligence Scale-Revised (WAIS-R) (Wechsler, 1981), the Broad Cognitive score from the standard battery on the Woodcock-Johnson Psychoeducational Battery-Revised (WJ-R) (Woodcock \& Johnson, 1989), and composite achievement test scores also from the WJ-R battery.

A variety of information could have been provided, but in the interest of parsimony, these few statistics were chosen. They include information about students' group membership as LD, nonlearning disabled (NLD), or enrolled in mostly adult education, non-credit classes. This latter group of approximately 15 students in adult education is a subset of the LD sample. This subset of adult education students was provided to have another contrast of student groups. The adult education group is not likely to be pursuing a college degree currently. Rather, they are participating for enrichment, retraining, or even to work on basic skills of the GED. For the different test scores, several numerical values are reported, including the number of students in the group (count), the mean score for the group, and several numbers that help describe the variation of scores within the group: the standard deviation (Std Dev), the standard error of the mean (Std Error), the minimum and maximum scores in the group (Min and Max), and the $95 \%$ confidence interval of the mean score ( $95 \%$ conf int).

These data confirmed several observations noted by Miller et al. (1990). In general, the mean level of performance on ability or aptitude and achievement measures was significantly lower for the students with LD than the general student population. The percentile rankings for these standard scores corresponded to approximately the 32 nd percentile down to the 13 th percentile. For the students without disabilities the mean scores were average and in a range of the 67 th to the 42 nd percentiles.

This information is important to teachers and potentially other IEP and ITP team members. As team members consider postsecondary options, these test scores might help members evaluate alternatives by comparing a student to two groups: (a) a student sample without disabilities and (b) a student sample with $\mathrm{LD}$. Although selective colleges may have stringent requirements and be appropriate to higherfunctioning students with LD (Adelman \& Vogel, 1990; Shaywitz \& Shaw, 1988), students with lower abilities have options as well. As can be observed in the pattern of scores, the achievement scores of students with LD are well below average, but that has not eliminated the community college option. With appropriate support services these students have achieved and through that experience improved their potential quality of life once they reach their educational goals.

Another indicator was participation in extracurricular activities in the school (Miller et al., 1990). These activities were quite varied and allowed the students with specific learning disabilities to demonstrate their strengths, which surely also contributed to higher self-esteem. The activities cited were athletics, music, speech, drama, and debate.

The last area to demonstrate a difference was that the students also were involved in the community. They learned which resources were available and how to use them. Important resources include job training and placement services, vocational rehabilitation services, and adult education.

These areas also are dependent on family support and emphasis. The linkage between students' outcomes and family support is well documented and should be considered one of the most important resources for a student (Edgar, 1987; Kravets, 1993a; Oliker, 1989; Quinby, 1989; Spekman, Goldberg, \& Herman, 1992). The school staff should encourage and foster this family resource.

The same themes are supported in the analysis of successful and unsuccessful young adults as described by Oliker (1989), Sitlington and Frank (1990), and Spekman et 
al. (1992). The latter authors noted several characteristics differentiating successful and unsuccessful adults. A realistic adaptation to life events was singled out as most important. This characteristic included self-awareness of strengths and weaknesses related to the learning disability, a proactive approach (meaning that they were involved in the world around them), and a willingness to persevere to their goals. This perseverance included a high level of emotional stability, ability to reduce personal stress, and coping strategies.

Another characteristic was goal-setting and goal-directed behaviors. These young adults had a vision of what they wanted to accomplish and willingness to reach the goal stepby-step. Oliker (1989) described this characteristic as motivation, which can be developed through home and school experiences. These experiences included students' participation in community and school activities. What these data seem to suggest is a significant paradox. Typically, students with LD are described as having few friends and limited social competence (Mellard \& Hazel, 1992), yet these areas are exactly the ones that must be developed to increase students' likelihood of success in a postsecondary setting and quality of life as an adult in the community. This paradox should be understood as professionals and parents support the student and plan the IEP and ITP.

Yet another characteristic of students who are successful in postsecondary educational settings is related to the presence and use of effective support systems in their lives. This characteristic is similar to the findings of Miller et al. (1990) in their analysis. The role of "significant others" in their lives was important-if not from family members, then from mentoring relationships they developed with others in the community or school system. The support system seems to be critical to community integration and goal-setting behaviors discussed earlier.

\section{HIGH SCHOOL TRANSITION ACTIVITIES}

For a student to become successful in postsecondary settings, the high school program can contribute valuable opportunities. NICHCY $(1991,1993)$ outlined several of the areas that can smooth the transition. In addition, our work in the adult education, vocational-technical, and community college settings has provided insight in several areas that also become important to college planning for students with LD. The goals of a high school program to smooth a student's transition to college are the following:

1. Developing students' effective study skills. Effective study skills are critical, as the independence of college and the higher level of academic expectations place an increased burden on college students.
2. Developing students' learning strategies. The strategies are quite inclusive in improving students' ability to acquire meaning from written text and produce documents that demonstrate their knowledge of the content in a style that communicates the writers' intent.

3. Arranging job tryouts to allow students opportunities to evaluate different career and vocational options. High school offers a great opportunity to inquire safely and test alternative vocational interests. Before rushing to the postsecondary setting, students can learn more about various career options that will help, not only in career plans but also in selecting a setting that will provide the needed educational experiences.

4. Arranging needed accommodations for college entrance exams and matriculation testing. Students are entitled to assessments that do not penalize them for their specific learning disability. These accommodations include extended time, a reader, a scribe, a separate testing area, or shorter test sessions. The important point is for the students to learn which accommodations work best for them and gain the needed documentation to support their requests for the accommodations in standardized testing, and, later, college classes.

5. Identifying colleges that provide educational programs relevant to career interests. For any student seeking college admission, the planning should begin early in high school. For the student with LD the choice might be more difficult because of issues related to special admissions and ensuring that the needed support services are available. Matching the desired educational program and level of needed support services is an important step in college selection.

6. Identifying the types of accommodations and support services that the student needs because of his or her disability. The differences between a high school and a college are readily apparent. High school provides opportunities to learn what instructional and assessment accommodations work best. Postsecondary programs are likely to place more emphasis on providing the accommodations that the student used in general classes.

7. Assistance in the application process. Applying to colleges and for financial aid packages can be a daunting task. The sometimes bewildering application process and the waiting period could be part of the reason that few students with LD enter postsecondary education. Support in this area could lead to higher enrollments by students with LD.

8. Assistance in preparing the documentation that the student can carry to the college. The high school setting provides many protections and coordinated services that are greatly reduced, if not eliminated, once the student exits. Documentation of the history of the disability and 
effective interventions represents a valuable resource that can guide administrators and counselors in working effectively with students and reducing the apprehension and frustration they encounter in learning a new system. This documentation should include results of a recent comprehensive evaluation, a summary of previous evaluations, and, most important, information on the type and extent of services that have been provided. The typical IEP does not provide this information.

Cardarella (1989) provided one example of documentation that was helpful in postsecondary settings and vocational rehabilitation and was cited as a "best practice." The two- to three-page student reports describe progress to date. The organization included main headings in the student's academic areas (e.g., math and English, including reading and writing) and related areas influencing achievement such as learning style, successful modifications and intervention strategies, work-related skills, and last, concerns about the student. The documentation is an effective way to summarize information that other service providers would use.

A good plan for preparing this information is to collaborate with staff in postsecondary settings. That staff likely would welcome an extended discussion on the information and its format that is particularly helpful as they consider admissions questions, academic counseling, and appropriate classes, services, and accommodations. At the postsecondary setting this information might prove valuable in overcoming the reported negative attitudes held by some faculty members who confuse ADA (Americans with Disabilities Act) with the American Dairy Association or American Dental Association (e.g., Brinckerhoff et al., 1992; Lundeberg \& Svien, 1988; Nelson et al., 1990; Putnam, 1984; Shaywitz \& Shaw, 1988).

A psychoeducational evaluation and an interview are important to more than half of the postsecondary personnel surveyed about LD eligibility procedures (Bursuck et al., 1989). The interview is likely the most common denominator of the LD assessment process used in a variety of settings and agencies. For this reason students should be familiar with both the process and the possible content of an intake procedure. In some instances students would be able to gather supporting documentation that could facilitate their answering the intake interview items.

An intake interview is one example of information that college staffs use in judging students' eligibility. It might be used for practice in completing written materials and for interviews. The California intake interview is used at more than 105 campuses and is accepted in the California State University and University of California systems. In the community college system the interview might be administered in one of three ways: (a) personal interview, (b) written application followed by personal interview, or (c) computerized administration with a college staff member. As students progress through the postsecondary programs and occupational settings, they will realize that they have to be their own advocates, which requires accurate, effective communication skills. An interview is an important part of most employment applications and admissions to professional schools.

\section{POSTSECONDARY STUDENT SERVICES}

High school students should begin their evaluation of postsecondary settings early, certainly by their junior year. At that age several factors enter into the students' evaluation equation to calculate which is the best postsecondary setting for them. The students might ask if they should attend (a) the most rigorous academic program in their subject matter area of interest, (b) the program with the best services for students with $L D$, or (c) the program that is least expensive and closest to home. For students of this age, the answer probably is (d) the program with the most favorable gender ratio! On the other hand, if the quality of available LD services is a consideration, teachers might want to have some methods for helping the student evaluate those services.

Services in postsecondary settings take a variety of forms. One of the earlier organizations for services was described by Ugland and Duane (1976). Their model made available two ways of serving the needs of LD college students:

1. The student adapts to existing institutional standards with help from counseling, tutoring, and support services.

2. The institution adapts its basic teaching and program requirements to the student's learning style.

These two alternatives may be inclusive; however, the philosophy for serving students with disabilities, the available services, legal and judicial foundations for services, and faculty attitudes have changed from this formation.

Vogel's (1985) listing of characteristics of a model comprehensive college LD program is quite an extensive revision of Ugland and Duane's description. The 15 characteristics Vogel identified encompass an important perspective of services. These LD program characteristics are paraphrased below. They provide teachers and students with a frame of reference for weighing the merits of services available on different campuses.

1. Planning and staff development precede initiation of an LD program.

2. The administration is $100 \%$ supportive of the program and its goals. 
3. An LD specialist has overall responsibility for the program.

4. Students with LD receive academic planning to ensure that they have a workable load.

5. The faculty is supportive of the LD program and its students.

6. The faculty is knowledgeable of legal requirements for accommodations and is supportive.

7. The staff includes trained assessment personnel who can complete psychoeducational evaluations and monitor student progress.

8. Students have an IEP and receive instruction in basic skills and compensatory techniques on a one-to-one basis.

9. Peer tutors provide support in coursework.

10. Accommodations (e.g., recorded textbooks, notetakers, readers, scribes) are available.

11. Modified examination procedures are accessible.

12. The LD staff and faculty communicate frequently.

13. Personal counseling, support groups, and peer advocates are available.

14. Career and life planning counseling is available.

15. Writing labs, math centers, language labs, study skills or learning centers are available and supported by a cooperative relationship between the LD specialists and the respective lab or center staffs.

From Vogel's listing the reader gets the distinct impression that a separate LD program exists for students. That model of a separate LD program is increasingly a rarity. What is more likely is an office or a program for students with disabilities. The program for students with disabilities serves all students with disabilities and may offer some services especially for students with $\mathrm{LD}$.

\section{Service Models}

Siperstein (1988) organized three types of service models in the postsecondary setting: (a) separate support services that augment regular college classwork; (b) services that center on a learning disability specialist and include tutoring, counseling, and advocacy; and (c) student services that are available to all students who identify themselves as having a disability. Vogel's description is similar to the (b) model described by Siperstein.

Kravets and Wax (1993) noted that no two postsecondary LD programs are alike but that similarities can be identified. In their review of college and university programs, they organized the available services into three categories. These have application for understanding services through any postsecondary setting and should be helpful in comparing alternative settings and matching settings to students' interests and needs. The three categories of programs are: (a) structured programs, (b) coordinated services, and (c) services.

\section{Structured Programs}

Colleges with structured programs offer the most comprehensive services for students with $\mathrm{LD}$. The director and staff are certified in LD or related areas. The director is involved actively in the admission decision, and the criteria for admission often are more flexible than general admission requirements. Services are highly structured, and students are involved in developing plans to meet their specific learning styles and needs. Often students participating in structured programs sign a contract agreeing to participate actively in the program. The services usually carry an additional fee. High school students who have participated in a structured program or structured services in high schoolsuch as a learning disabilities resource program, individualized or modified coursework, tutorial assistance, academic monitoring, notetakers, test accommodations, and skill classes - might benefit from exploring colleges with structured programs.

\section{Coordinated Services}

Coordinated services differ from structured programs in that the services are not as comprehensive. These services usually are provided by at least one certified LD specialist. The staff is knowledgeable and trained to provide assistance to students to develop strategies for their individual needs. The director of the program or services may be involved in the admission decision or in a position to assist students with an appeal if they are denied admission to the college. To receive these services generally requires specific documentation of the LD, and students are encouraged to self-identify prior to entry. Students voluntarily request accommodations or services in the coordinated services category, and specific skills courses or remedial classes may be available or required for students with LD who are admitted probationally or conditionally. High school students who may have enrolled in some modified courses, utilized test accommodations and required tutorial assistance but who typically requested services only as needed might benefit from exploring colleges with coordinated services or services.

\section{Services}

Of the three categories, services is the least comprehensive. Colleges offering services usually provide assistance to all students. Most colleges require documentation of the disability if the student with LD is to receive accommodations. Staff and faculty support students with LD actively by providing basic services to meet the students' needs. Services are requested on a voluntary basis, and some limitations may be placed on the services available. Sometimes the 
small size of the student body enables the necessary personal attention to help students with LD succeed in college. High school students requiring minimum accommodations might benefit from and find comfort in knowing that services are available, knowing who the contact person is, and knowing that this person is sensitive to students with LD (Kravets \& Wax, 1993, p. 1).

The student, parents, and teacher should be able to identify which of the three levels of services are most appropriate. The level of services the student needs also can vary with factors such as other support structures, difficulty of the field of study, the student's background preparation, anticipated academic course load and study requirements, and the negative influence of competing activities such as extracurricular activities and familial or job responsibilities. Students certainly should prepare their list of anticipated needed services and use that list as one guide in interviewing prospective institutions or reviewing their materials.

The following list of services from the California community colleges was developed as we worked with LD specialists there to identify a set of core services:

1. Individualized LD eligibility assessment

2. Academic counseling

3. Liaison with faculty members

4. Tutoring services

5. Vocational counseling

6. Special classes in LD

7. Personal counseling

8. Registration assistance

9. Liaison with campus and community agencies

10. Special materials and supplies

11. Special matriculation assistance

12. Job placement and development

13. Test-taking facilitation

14. Notetakers

15. Books on tape

This list reflects a range of academic, vocational, and personal services that fosters a smooth transition to a 2-year college program. The quality and organization of these services vary with the training and personality of the service providers and also institutional factors such as the college's perceived mission in postsecondary education. For example, colleges that emphasize later transfer to a 4-year setting have a different focus than settings with a vocational orientation.

As a class project students could develop a survey of postsecondary programs. The survey could elicit information regarding admissions standards, LD program eligibility standards, accommodations used frequently, grievance procedures, contact persons for services, enrollment numbers of students with LD, and gender ratios. The returned surveys could be organized into a notebook for future reference and updated as each year's class matriculates. The project not only would gather relevant information but also could stimulate interest in available postsecondary options. Two suggestions about this project are to: (a) do a little pilot test of the survey with a couple of college recruiters and parents of students; the parents can give some insight into the information they value in making a decision; and (b) survey a broad range of programs such as area vocational, technical programs, community colleges, proprietary colleges, professional schools, small, selective colleges, and public colleges and universities. Three journal articles that provide extensive reviews of the surveys they used in gathering information about the postsecondary services to students with LD are Beirne-Smith and Deck (1989), Bursuck et al. (1989), and Parks, Antonoff, Drake, Skiba, and Soberman (1987). Teachers might find their reviews helpful as resource material for similar activities undertaken with students.

On some campuses special courses are available to students with learning disabilities. Sierra College, for example, has a course titled "Learning Disabilities Orientation," which provides .5 units and is graded as credit/noncredit. The course is described as a 9-hour orientation to the college's LD program and assessment of learning strengths and weaknesses to determine eligibility for LD services using the step-by-step guidelines mandated by the California community college system. The assessment includes an intake interview, a perceptual assessment battery, and a combination of aptitude or intelligence testing and achievement battery. When a student is found to be eligible for LD services, the LD specialist works with the student to prepare an IEP. The current textbook for the class is Carol Wren and Laura Segal's (1985) treatment about college students with LD.

Why would a college, such as Sierra College, offer a nontransfer course on LD assessment? Some students are required to maintain a minimum number of hours as a condition for receiving other services or as part of a work-study or loan program. Such an elective helps the student meet requirements for a minimum number of hours. More often than not, postsecondary institutions require a student to pay a fee or seek an independent evaluation for purposes of identification and eligibility. The fees for evaluations typically run from $\$ 200$ to $\$ 1,000$. This expense may be prohibitive. Thus, several advantages exist for the student. The college also benefits because the students are counted toward the program's enrollment, as a basis for funding. Through the program's weighted funding formula the enrollment can generate dollars. This option is the one way a college can recoup from the state some of the costs associated with individual psychoeducational evaluations. 


\section{Accommodations, Substitutions, and Waivers}

In comparison to secondary settings, student services in most postsecondary settings (a) vary even more extensively, (b) are not as well developed programmatically, and (c) are not multidisciplinary. In one review of postsecondary services and service delivery models, the authors concluded that programs were "stringing together" services with limited potential for fostering success (McGuire, Norlander, \& Shaw, 1990). We have reviewed a number of legislative and legal differences between these two settings that influence student services. Unless those mandates change, the postsecondary setting will continue to be weighted toward advocacy and informational services rather than direct interventions.

Three topics are particularly important regardless of how the services are organized. Those three topics concern: (a) the academic related accommodations that you might expect, (b) the substitutions of curricular courses, and (c) the waiver of particular degree requirements. We probably would have grave concerns if students with LD, who were studying to be surgeons, were granted course waivers because they felt nauseous at the sight of blood. On the other hand, we would consider an oral exam permissible if the students' written expression was so poor that they could not communicate in a written form. We would want assurance that the deficit was not related to poor motor coordination or the students' ability to make accurate incisions or sew stitches. These issues of accommodations and course variances are important for a student's success and are also issues that the student and the transition team can consider along with postsecondary setting options.

Appropriate accommodations vary extensively but can be organized into four areas using a framework described by Nelson et al. (1990): (a) instruction, (b) assignments, (c) examinations, and (d) special assistance. At issue is which accommodations are appropriate to the student and under what conditions they can be applied. Programs are not likely to provide a one-size-fits-all mentality to determine accommodations. Using accommodations in high school and documenting their use is important to building a history of the disability that will be of benefit to college admissions and their use in postsecondary classes. Documenting previous experience with a given accommodation should be persuasive to college faculty to allow a student to continue to use it as needed.

Course substitutions can be used in conjunction with accommodations. In a course substitution the student seeks to replace a course with an alternative that does not have the requirements or content that limited the student's ability to perform. Course substitutions are considered major decisions in that they are not decisions made by the individual instructor alone. Substitutions involve decisions at the departmental and institutional levels. As such, they require carefully developed justification. The postsecondary program should entail extensive discussion about the basis of the request, the legal and curricular documentation supporting the request, and an understanding of criteria on which to base the decision. A valid concern of the postsecondary program is that other students, for a variety of other reasons, might seek a substitution as well. The response should be carefully reasoned to preclude any action that later might be misconstrued as arbitrary.

Take the case of a college with a foreign language requirement and a student with a language deficit. A language course might be replaced with a course in computer language. Many might think computers are so foreign that the substitution is not compatible. Suffice it to say that replacing a Spanish or French foreign language competency with a Pascal, Cobol, or C computer language competency might be workable. The department likely will want to compare all of the intended outcomes of a language requirement with any from a proposed substitution. For that reason, the student seeking a substitution should understand the basis for the department's language requirement.

A second substitution might be considered for an individual with dyscalculia. If the person has problems with math calculations, the substitution might be to take a logic course in place of an algebra course. Both courses teach a system of thinking. Practically speaking, the substitution might work for individuals whose intended careers are oriented to areas with minimal mathematical requirements and who become skilled with computational prosthetics such as calculators.

A third option is a course waiver. This option is least likely because of the implication that the course or an equivalent is inappropriate to the major area of study. A waiver suggests that the major area of study can be defined without specific or closely related content.

\section{Identification Versus Eligibility Assessment}

Most students-most all of us, for that matter-find testing annoying at best, and a basis for great fear, indigestion, sleeplessness, and heightened anxiety. Because most of us like to avoid unpleasantness, understanding LD-related assessments might be useful. The distinction between identification and eligibility assessments sometimes is blurred and yet is important to distinguish. The outcomes from these two assessments are different. Students with a history of learning disability have been judged eligible for services and placement as described on the IEP, These decisions were made through referral, evaluation, and placement processes prescribed in federal (e.g., Public Laws 94-142 and 101$467)$ and state legislation and regulations and local school district plans. 
Postsecondary settings do not have comparable legally binding mandates. No federal or state regulations describe the processes that the postsecondary system must follow to identify students with LD or determine whether students with LD should or should not receive special services. In addition, rarely do these postsecondary settings freely provide assessment services for diagnosing whether a student has a learning disability. Although assessment is readily available, significant costs can be associated with this service. Considering the emotional toll, time requirements, and related financial costs, the assessments should be as minimal as possible.

In the postsecondary setting the concern is less with identification and more with eligibility. In this setting the concern is whether the student's disability is serious enough to warrant services and, if so, to determine the appropriate services. This largely reflects the emphasis in federal legislation, Section 504 of the 1973 Rehabilitation Act. The problem that college staffs confront is that their students do not come from a single $\mathrm{K}-12$ setting. The students don't matriculate through the grade levels as they do in a single school district wherein students pass along from one grade to the next and from one attendance center to the next center in a grade-based order (e.g., grade school to middle school to junior high to senior high school). Students enroll in postsecondary settings from a variety of school districts from a variety of states. Also, postsecondary settings are confronting a rise in the number of nontraditional students whose age and experience distinguish them from the traditional student who is more likely to begin college-related courses within a year or two after leaving high school. This lack of consistency in students' background experiences poses new challenges in the postsecondary setting and a great opportunity for high school special educators.

Postsecondary institutions enroll students with an LD diagnosis from a variety of programs including public school multidisciplinary teams, vocational rehabilitation programs, adult literacy programs, mental health services, medical centers, commercial learning centers, and privatepractice physicians. The physician might be a neurologist, an optometrist, a chiropractor, or a pediatrician. Each of these service providers likely works from his or her own identification model and definition of learning disabilities. The definitions are tailored to the clients they serve, their financial support, and the services they provide. Therefore, postsecondary staffs would be wise not to compare one diagnostic model to another but, rather, approach the issue of whether sufficient documentation supports students' claims of disability and whether the disability is severe enough to distinguish them from the general student body and to warrant special services. This perspective allows the college to describe eligibility requirements for services.
Students making the application should know who has the responsibility of making these decisions at the institution. One may be able to make the case that an LD specialist employed in a postsecondary setting would have a different view than a staff member in the admissions office.

Postsecondary institutions are particularly concerned with three aspects of verifying that students have disabilities. Any of the following would entitle a student to services as disabled:

1. The student has a diagnosis of a disability.

2. The student has a history of a disability.

3. The student has been treated as if he or she has a disability.

If any one of these conditions is met, the student likely will be eligible for services in the postsecondary setting. The teacher and the student need to recognize the emphasis these perspectives place on the student to clearly document information about the disability and the support services and accommodations that are warranted. Colleges are apt to be more concerned with maintaining their tradition of academic rigor and less with compromising their standards for excellence (Brinckerhoff et al., 1992).

The collaborative team for an IEP and ITP has to differentiate among various assessments. One of the great services teachers can provide to students in transition consists of updated, appropriate assessments. The resulting information is important to postsecondary staffs as they make their eligibility decisions. In selecting assessments, several simple rules are useful:

1. Choose assessments that demonstrate students' disabilities and strengths. The postsecondary staff wants to provide appropriate services and accommodations. Students are not understood just by their weaknesses for which accommodations may be provided. Understanding students' strengths also helps in evaluating students' goals, degree interests, and course selections. For example, college coursework provides few tasks in which words have to be recognized in isolation but does require extensive reading of meaningfully connected prose. This suggests that information on a reading test that presents only words in isolation, such as the Wide Range Achievement Test Reading subtest (Jastak \& Wilkinson, 1984) or the Woodcock Reading Mastery Test Word Identification subtest (Woodcock, 1987), is of limited value. A much better alternative would be something like the Degrees of Reading Power (Koslin, Koslin, Zeno, \& Ivens, 1989) test. The task of reading words in isolation may be of diagnostic value in determining the student's phonetic processing, but 
the real task is in acquiring meaning in connected prose.

2. Include a normative comparison of a standard score and percentile rank. A student's portfolio of completed work or results of curriculum-based measurements can tell an important story about the student's success and level of skills and abilities. This story is incomplete without providing a broader context for understanding the student's achievement levels. The team members likely would feel uncomfortable in representing only the student's normative performance on the basis of a group-administered, standardized instrument. The individually administered test battery not only provides clinical information but also can be chosen to provide a better match of the student's strengths and weaknesses. For these reasons the standardized, normative measures should be included. The main concern should be with ensuring a smooth transition of the student from the secondary program to a host of other agencies with different agendas and eligibility requirements.

3. Don't put a lot of emphasis on the intellectual assessment. Tests of intellectual ability usually are administered as a matter of routine. Unless a significant pattern occurs in the scores or a shift in the score pattern is demonstrated across time, the only interest will be in having an index of the student's abilities as assessed on a standardized instrument. These scores should be interpreted as reflecting the lowest level of the student's abilities. The intellectual assessment might be thought of as reflecting the student's disabilities in composite scores, such as the Full Scale IQ or Extended Broad Cognitive Ability score. These scores set the minimum level of expected achievement. The staff should be especially interested in an estimate of the student's learning capacity in areas distinct from the disability. For that reason, patterns of scores may be of interest. The patterns should be interpreted in light of empirically demonstrated evidence that they are stable, distinct, and have meaningful interpretations. An extensive folklore is attached to some traditional IQ scores that requires skepticism.

4. Think of the assessment in broad terms. School teams tend to focus on academic and aptitude assessments, and for good reason. For students of secondary school age, however, social competencies become particularly important. The differences we have highlighted between postsecondary and high school settings provide a rationale for this increased shift in emphasis to social competency, community integration, and adaptive behavior (Siperstein, 1988).
Assessing social competence is more difficult. Try to include a number of instruments and reports from several individuals (e.g., teachers, the student, parents or guardians, and psychologists) to provide multiple perspectives on students' social competencies.

5. Encourage documentation about current instructional delivery methods and accommodations that work for the student. Documenting the instructional methods and current related goals for the student allows the postsecondary staff to assess more completely their potential suitability for the student in the new setting. This documentation includes information about what doesn't work or has not been successful with the student (e.g., success with the student completing work independently, success in the student's working with a same-age tutor, the student's awareness of academic strengths, the student's ability to self-monitor the accuracy of classwork and assignments, time management skills, and ability to organize work materials). The materials should be organized with consideration of who will be reviewing them. An admissions counselor will want a different level of details than an LD specialist.

\section{SUMMARY}

Should students with LD prepare for postsecondary options in high school? Without hesitation, the answer is "yes." At some point increased education may not improve one's quality of life. Even so, we might speculate that we lack sufficient evidence for students with $\mathrm{LD}$ to even guess what that point might be. Nevertheless, we can document clearly, from a library of follow-along and follow-up studies, that students currently are not often realizing any advantages from postsecondary education. Halpern (1993) likely would agree that most students with LD encounter a period of "purposeless unengagement" or, even worse, a period of self-denigrating or antisocial behavior. We argue that, though continued postsecondary education does not guarantee physical or material well-being, successful performance of adult roles, or personal fulfillment, a strong enough association exists that postsecondary alternatives should be considered and developed.

Can students make successful transitions to postsecondary settings? The answer is a qualified "yes." Based on the material we have presented, success depends on a lengthy list of considerations that influence' the outcome. For that reason, the discussion of postsecondary options should begin early, include a variety of perspectives and information, and become the student's major research project during the early years of high school. As Halpern (1985) suggested, the objective and subjective indices of quality of 
life may have a closer relationship once more attention is given to student interests and preferences in developing transition plans.

The differences between the high school and postsecondary milieus are more than cosmetic. Postsecondary experiences have proven advantageous to some students and disadvantageous to other students. The postsecondary setting has its barriers that should be acknowledged and considered in evaluating alternative settings. Programmatic factors influencing the transition outcome include the organization of student services and how accommodations, substitutions, and waivers can be applied to students with LD to meet degree and setting requirements. A distinction has to be made between assessment outcomes: identification as LD and eligibility for LD services. From a student's perspective, the preeminent issue is having the disability and intervention strategies documented for the admissions office in the postsecondary setting.

Planning for the transition to postsecondary settings of students with LD may seem like a formidable hurdle to the high school staff. Yet, students' successful transition and quality of life are goals shared by a number of people. Students with LD, like all students, should receive opportunities for success in the postsecondary setting.

\section{REFERENCES}

Adelman, P, B., \& Vogel, S. A. (1990). College graduates with learning disabilities-Employment attainment and career patterns. Learning Disability Quarterly, 13, 154-156.

Alexander, J., \& Rolfe, J. (1992). MatchMaker. Evanston, IL: Keystone Group.

Beirne-Smith, M., \& Deck, M. D. (1989). A survey of postsecondary programs for students with learning disabilities. Journal of Learning Disabilities, 22, 456-457.

Brinckerhoff, L. C., Shaw, S. R, \& McGuire, J. M. (1992). Promoting access, accommodations, and independence for college students with learning disabilities. Journal of Learning Disabilities, 25, 417-429.

Bruck, M. (1985). The adult functioning of children with specific learning disabilities: A follow-up study. In L. Siegel (Ed.), Advances in applied developmental psychology (pp. 91-129). New York: Ablex.

Bruck, M. (1987). The adult outcomes of children with learning disabilities. Annals of Dyslexia, 37, 252-264.

Bursuck, B. D., Rose, E., Cowen, S., \& Yahaya, M. A. (1989). Nationwide survey of postsecondary education services for students with learning disabilities. Exceptional Children, 56, 236-245.

Cardarella, J. (1989). High school teachers' summary of learning disabled graduates' strengths, weaknesses and learning styles. In Vocational Studies Center, Successful vocational rehabilitation of persons with learning disabilities: Best practices (pp. 237-243). Madison: University of Wisconsin.

Chancellor's Office. (1993). Intake screening and eligibility record. Sacramento: California Community Colleges, Disabled Students Program and Services.
Chancellor's Office. (1988). Program development and management manual. Sacramento: California Community Colleges, Disabled Students Program and Services.

Clark, G. M., \& Kolstoe, O. R. (1990). Career development and transition education for adolescents with disabilities. Needham Heights, MA: Allyn \& Bacon.

Cobb, R. M., \& Crump, W. D. (1984). Post-school status of young adults identified as learning disabled while enrolled in public schools: A comparison of those enrolled and not enrolled in learn ing disabilities programs. University of Alabama, Department of Education. (ERIC Document Reproduction Service No. 253 029)

Council for Learning Disabilities. (1993). The college experience for students with learning disabilities. Infosheet, October.

Dalke, C., \& Schmitt, S. (1987). Meeting the transition needs of college bound students with learning disabilities. Journal of Learning Disabilities, 20, 176-180.

Davie, A. R. (1987). Young adults with learning disabilities and other special needs. Washington, DC: Heath Resource Center.

Dowdy, C. A., Carter, J. K., \& Smith, R. E. C. (1990). Differences in transitional needs of high school students with and without learning disabilities. Journal of Learning Disabilities, 23, 343-348.

Eagle, E., Fitzgerald, R., Gifford, A., Zuma, J., \& MPR Associates. (1988). A descriptive summary of 1980 high school sophomores: Six years later. Washington, DC: U.S. Department of Education.

Edgar, E. (1987). Secondary programs in special education: Are many of them justifiable? Exceptional Children, 53, 555-561.

Elksnin, L. K., \& Elksnin, N. (1996). Strategies for transition to employment setting. In D. D. Deshler, E. S. Ellis, \& B. K. Lenz (Eds.), Teaching Adolescents With Learning Disabilities (2nd ed., pp. 525-578). Denver: Love Publishing.

Fairweather, J. S., \& Shaver, D. M. (1991). Making the transition to postsecondary education and training. Exceptional Children, 57, 264-270.

Fourqurean, J. M., \& LaCourt, T. (1990). A follow-up of former special education students: A model for program evaluation. Remedial and Special Education, 12(1), 16-23.

Fourqurean, J. M., Meisgeier, C., Swank, R. R., \& Williams, R. E. (1991). Correlates of postsecondary employment outcomes for young adults with learning disabilities. Journal of Learning Disabilities, 24, 400-405.

Halpern, A. S. (1985). Transition: A look at the foundations. Exceptional Children, 51, 479-486.

Halpern, A. S. (1993). Quality of life as a conceptual framework for evaluating transition outcomes. Exceptional Children, 59, 486-498.

Haring, K. A., Lovett, D. L., \& Smith, D. D. (1990). A follow-up study of recent special education graduates of learning disabilities programs. Journal of Learning Disabilities, 23, 108-113.

Jastak, S., \& Wilkinson, G. S. (1984). Wide range achievement test-Revised. Wilmington, DE: Jastak Associates.

Jones, C., Sebring, P., Crawford, I., Spencer, B., \& Butz, M. (1986a). High school and beyond: 1980 senior cohort second follow-up (1984). Washington, DC: U.S. Department of Education.

Jones, C., Sebring, P., Crawford, I., Spencer, B., \& Butz, M. (1986b). High school and beyond: 1980 sophomore cohort second followup (1984). Washington, DC: U.S. Department of Education.

Koslin, B. L., Koslin, S., Zeno, S. M., \& Ivens, S. H. (1989). Degrees of reading power. Brewster, NY: Touchstone Applied Science Associates.

Kravets, M. (1993a, September). College and post-secondary options. Presentation at National Center for Learning Disabilities, Educational Summit, Scottsdale, AZ. 
Kravets, M. (1993b). The college planning handbook for students with learning differences. Deerfield, IL: Deerfield High School.

Kravets, M., \& Wax, I. F. (1993). The $K \& W$ guide to colleges for the learning disabled. New York: Harper Collins.

Lundeberg, M., \& Svien, K. (1988). Developing faculty understanding of college students with learning disabilities. Journal of Learning Disabilities, 21, 299-300, 306.

Malcolm, C. B., Polatajko, H. J., \& Simons, J. (1990). A descriptive study of adults with suspected learning disabilities. Journal of Learning Disabilities, 23, 518-520.

Mangrum, C. T., \& Strichart, S. S. (1988). College and the learning disabled student ( $2 \mathrm{~d}$ ed.). Orlando, FL: Grune \& Stratton.

McGuire, J. M., Norlander, K. A., \& Shaw, S. F. (1990). Postsecondary education for students with learning disabilities: Forecasting challenges for the future. Learning Disabilities Focus, 5, 69-74.

Mellard, D. F. (1990). The eligibility process: Identifying students with learning disabilities in the California community colleges. Learning Disabilities Focus, 5, 75-90.

Mellard, D. F. (1993). Learning disabilities model development study technical report. Sacramento: Chancellor's Office, California Community Colleges, Disabled Students Program and Services.

Mellard, D. F., \& Clark, G. M. (1992). National high school project: Vol. 2. A quantitative description of concepts and practices for students with disabilities. Lawrence: University of Kansas. (ERIC Document Reproduction Service No. ED 355-685)

Mellard, D. F., \& Deshler, D. D. (1984). Modeling the condition of learning disabilities on post-secondary populations. Educational Psychologist, 19, 188-197.

Mellard, D. F., \& Hazel, J. S. (1992). Social competencies as a pathway to successful life transition. Learning Disabilities Quarterly, $15,251-273$.

Miller, R. J., Snider, D., \& Rzonca, C. (1990). Variables related to the decision of young adults with learning disabilities to participate in postsecondary education. Journal of Learning Disabilities, 23, 349-354.

National Information Center for Children and Youth with Disabilities. (NICHCY). (1991, September). Options after high school for youth with disabilities. Transition Summary, 7.

National Information Center for Children and Youth with Disabilities. (NICHCY). (1993). Transition Services in the IEP. Transition Summary, 3(1).

National Joint Committee on Learning Disabilities. (1994). Secondary to postsecondary education transition planning for students with learning disabilities. LDA Newsbriefs, 29(2), 3-5.

Nelson, J. R., Dodd, J. M., \& Smith, D. J. (1990). Faculty willingness to accommodate students with learning disabilities: A comparison among academic divisions. Journal of Learning Disabilities, 23, 185-189.

Neubert, D. A., Tilson, G. P., \& Ianacone, R. N. (1989). Postsecondary transition needs and employment patterns of individuals with mild disabilities. Exceptional Children, 55, 494-500.

Oliker, N. (1989). Class privilege and the status of learning disabled students at selective institutions. Latest Developments, Fall, pp. 1-3. (Association of Handicapped Student Service Programs in Postsecondary Education, Columbus, $\mathrm{OH}$ )

Osgood-Smith, J. (1992). Falling through the cracks: Rehabilitation services for adults with learning disabilities. Exceptional Children, $58,451-460$.

Parks, A. W., Antonoff, S., Drake, C., Skiba, W. E., \& Soberman, J. (1987). A survey of programs and services for learning disabled students in graduate and professional school. Journal of Learning Disabilities, 20, 154, 181-187.
Prater, G., \& Minner, S. (1986). Factors inhibiting the performance of learning disabled students in postsecondary settings. Reading, Writing, and Learning Disabilities, 2, 273-277.

Putnam, M. L. (1984, January). Postsecondary education for learning disabled students: A review of the literature. Journal of College Student Personnel, pp. 68-75.

Quinby, S. E. (1989). A response to "Class Privilege and the Status of Learning Disabled Students at Selective Institutions." Latest Developments, Fall, pp. 1-3. (Association of Handicapped Student Service Programs in Postsecondary Education, Columbus, $\mathrm{OH})$

Rojewski, J. W. (1989). A rural based transition model for students with learning disabilities: A demonstration. Journal of Learning Disabilities, 22, 613-620.

Rosenthal, I. (1986). New directions for service delivery to learning disabled youth and young adults. Learning Disabilities Focus, 2, 55-61.

Scuccimarra, D. J., \& Speece, D. L. (1990). Employment outcomes and social integration of students with mild handicaps: The quality of life two years after high school. Journal of Learning Disabilities, 23, 518-520.

Shapiro, E. S., \& Lentz, F. E. (1991). Vocational-technical programs: Follow-up of students with learning disabilities. Exceptional Children, 58, 47-59.

Shaywitz, S. E., \& Shaw, R. (1988). The admissions process: An approach to selecting learning disabled students at the most selective colleges. Learning Disabilities Focus, 3, 81-86.

Siegel, S., \& Gaylord-Ross, R. (1991). Factors associated with employment success among youths with learning disabilities. Journal of Learning Disabilities, 24, 40-47.

Siegel, S., Robert, M., Waxman, M., \& Gaylord-Ross, R. (1992). A follow-along study of participants in a longitudinal transition program for youths with mild disabilities. Exceptional Children, 58, 346-356.

Siperstein, G. N. (1988). Students with learning disabilities in college: The need for a programmatic approach to critical transitions. Journal of Learning Disabilities, 21, 431-436.

Sitlington, P., \& Frank, A. R. (1990). Are adolescents with learning disabilities successfully crossing the bridge into adult life? Learning Disabilities Quarterly, 13, 97-111.

Sitlington, P., \& Frank, A. R. (1993). Dropouts with learning disabilities: What happens to them as young adults? Learning Disabilities Research and Practice, 8(4), 244-252.

Spekman, N. J., Goldberg, R. J., \& Herman, K. L. (1992). Learning disabled children grow up: A search for factors related to success in the young adult years. Learning Disabilities Research and Practice, 7, 161-170.

Ugland, R., \& Duane, G. (1976). Serving students with special learning disabilities in higher education-A demonstration project at three Minnesota community colleges. Bloomington, MN: Normandale Community College. (ERIC Document Reproduction Service No. ED 135 434)

Valdes, K. A., Williamson, C. L., \& Wagner, M. M. (1990). The national longitudinal transition study of special education students, statistical almanac, volume 2: Youth categorized as learning disabled. Palo Alto, CA: SRI International.

Van Reusen, A., \& Bos, C. S. (1994). Facilitating student participation in individualized education programs through motivation strategy instruction. Exceptional Children, 60, 466-475.

Vogel, S. A. (1985). The college student with a learning disability: A handbook for college LD students, admissions officers, faculty, and administrators. Lake Forest, IL: Barat College. 
Vogel, S. A., \& Sattler, J. L. (1981). The college student with a learning disability: A handbook for college and university admissions officers, faculty, and administration. DeKalb: Illinois Council for Learning Disabilities.

Wechsler, D. (1981). Wechsler adult intelligence scale-Revised. New York: Psychological Corp.

Wehman, R., Kregel, J., \& Barcus, J. M. (1985). From school to work: A transition model for handicapped students. Exceptional Children, 52, 25-37.

Will, M. (1985). Transition: Linking disabled youth to a productive future. OSERS News in Print, Washington, DC: U.S. Department of Education, Office of Special Education Services.
Woodcock, R. W., (1987). Woodcock reading mastery tests-Revised. Circle Pines, MN: American Guidance Service.

Woodcock, R. W., \& Johnson, M. B. (1989). Woodcock-Johnson psychoeducational battery-Revised. Chicago: Riverside Publishing.

Wren, C., \& Segal, L. (1985). College students with learning disabilities: A student's perspective. Chicago: DePaul University, Project Learning Strategies.

\section{PERMISSIONS AND COPYRIGHT}

All rights are reserved. No part of this publication may be reproduced, photocopied, faxed, stored in a retrieval system, or transmitted in any form or by any means, electronic, mechanical, recording or otherwise, without the prior written permission of the publisher.
Back issues are available for sale. Reproduction requires permission and payment of fees. It is illegal and a violation of federal copyright law to reproduce this publication without permission. Direct all inquiries to the permissions editor. 
INDEX ・ Volume 37

\section{Author Index}

Capizzi, Andrea M. (February 2005)

Cook, Mary N. (March 2005)

Cratty, Bryant J. (November 2004)

Crowley, E. Paula (April 2005)

DiPaola, Michael (September 2004)

Fuchs, Douglas (February 2005)

Fuchs, Lynn S. (February 2005)

Guetzloe, Eleanor (April 2005)

Johns, Beverley H. (April 2005)

Knackendoffel, E. Ann (January 2005)

Mellard, Daryl (May 2005)

Murtadha-Watts, Khaula (October 2004)

Seeley, Ken (December 2004)

Stoughton, Edy (October 2004)

Tschannen-Moran, Megan (September 2004)

Walther-Thomas, Chriss (September 2004)

\section{Chronological Index of Titles}

School Principals and Special Education: Creating the Context for Academic Success (September 2004)

Critical Cultural Knowledge in Special Education: Reshaping the Responsiveness of School Leaders (October 2004)

Adapted Physical Education: Self-Control and Attention (November 2004)

Gifted and Talented Students at Risk (December 2004)

Collaborative Teaming in the Secondary School (January 2005)

Identifying Appropriate Test Accommodations for Students With Learning Disabilities (February 2005)

The Disruptive or ADHD Child: What to Do When Kids Won't Sit Still and Be Quiet (March 2005)

The Central Role of Teaching Social Skills (April 2005)

Strategies for Transition to Postsecondary Educational Settings (May 2005) 